\title{
Türkiye'de Uygulanan Afet Yönetimi Politikalarının İncelenmesi: Yasal Düzenlemeler ve DASK
}

\author{
Gülcan AZIMLLi ÇíLiNGíR ${ }^{1}$
}

Öz

Türkiye'de afet yönetimi örgütlenmesine ilişkin yasal düzenlemeler, daha önceleri meydana gelen her doğa olayından sonra, o olaya ilişkin özel bir kanunun çıkarılmasıyla gelişmiştir. Ancak, yasal düzenlemeler açısından, Türkiye'de afet yönetimi ve koordinasyonu alanında dönüm noktası 1999 Marmara Depremi olmuştur. Büyük can kaybına ve geniş çaplı hasara neden olan bu deprem, ülkemizdeki afet yönetimi sisteminin yetersizliklerini ve dünyada gelişen afet yönetimi anlayışına uygun yeni politikaların geliştirilmesi zorunluluğunu ortaya koymuştur. Marmara depreminin hemen ardından, bölgede normal yaşama dönülebilmesi ve gereken yasal önlemlerin ivedilikle alınabilmesi amacıyla, 4452 Sayılı "Doğal Afetlere Karşı Alınacak Önlemler ve Doğal Afetler Nedeniyle Doğan Zararların Giderilmesi İçin Yapılacak Düzenlemeler Hakkında Yetki Kanunu" ile hemen ardından çok sayıda kanun, KHK, tüzük ve yönetmelik çıkarılmıştır. Yetki Kanunu'na dayanılarak hazırlanan 587 Sayılı "Zorunlu Deprem Sigortası'na Dair KHK” yürürlüğe girmiştir. Söz konusu KHK ile kapsamdaki konutlar için ZDS yapmak üzere Doğal Afet Sigortaları Kurumu (DASK) kurulmuştur.

Bu çalışmada, ülkemizde uygulanan afet yönetimi politikaları mevcut yasal düzenlemeler ele alınarak incelenecek; deprem nedeniyle maddi zarara uğrayanlar için teselli niteliğinde olacak maddi desteğin kısa sürede sağlanabilmesi amacıyla ortaya çıkan DASK'ın özellikleri ele alınacaktır.

Anahtar Kelimeler: Afet, Afet Politikası, Yasal Düzenleme, DASK.

\section{Investigation of Disaster Management Policies Used in Turkey: Legal Regulations and Turkish Natural Catast Catastrophe Insurance Pool}

\begin{abstract}
Regulations related to disaster management organization in Turkey, after every incident of natüre that preceded it, it developed with a special law concerning it. Howeever, in terms of legal regulations, Turkey in the field of disaster management and coordination has been the turning point in the 1999 Marmara earthquake. This earthquake, which causes large casualties and large diameter casings. The disadvantages of the disaster management system in our country and the necessity of developing new policies in accordance with the understanding of disaster management in the World. Immediately after the Marmara earthquake, in order to be able to return to normal life in the region and to take necessary legal measures urgently, Numerous laws, decrees, statutes and regulations have been
\end{abstract}

\footnotetext{
${ }^{1}$ Ar. Gör., Van Yüzüncü Yıl Üniversitesi iïiBF Kamu Yönetimi Bölümü Hukuk Bilimleri ABD.,

*Ilgili yazar / Corresponding author: gulcanazimli@gmail.com

Gönderim Tarihi: 06.04.2018

Kabul Tarihi: 26.04.2018
}

Bu makaleye atıf yapmak için- To cite this article Azimli Çilingiroğlu, G. (2018). Türkiye'de Uygulanan Afet Yönetimi Politikalarının Incelenmesi: Yasal Düzenlemeler ve DASK. Resilience, 13-21. . 
issued immediately following the Law No. 4452 on "Authorization Law on the Measures to be Taken Against Natural Disasters and the Measures to be Taken Against Natural Disasters". Decree Law No. 587 on Compulsory Earthquake Insurance, which was prepared based on the Authority Law, entered into force. Turkish Natural Catast Catastrophe Insurance Pool was established in order to make Compulsory Earthquake Insurance for the residences in the scope of the Decree-Law.

In this study, disaster management policies implemented in our country will be examined by considering the current legal regulations; Turkish Natural Catast Catastrophe Insurance Pool will be dealt with in order to ensure that the financial support to be provided in the form of consolation for those who suffer financial damages due to the earthquake in a short time.

Keywords: Disaster, Disaster Policy, Legal Regulation, Turkish Natural Catast Catastrophe Insurance Pool.

\section{1- $\quad$ Afet Yönetim Sistemi Politikalarına Genel Bakış}

Afet yönetimi; afetlerin önlenmesi ve afet zararlarının azaltılması amacıyla, afetin öncesi ve sonrasında yapılacak çalışmaların planlanması, yönlendirilmesi, koordine edilmesi, desteklenmesi ve uygulanabilmesi için toplumun tüm kurum ve kuruluşlarının katılımıyla, kaynaklarının bu ortak hedefler doğrultusunda yönetilmesini gerektiren çok geniş bir kavram olarak karşımıza çıkmaktadır. Afet yönetiminin kaynaklarda, yerinde bir ifadeyle" Kapsamlı Afet Yönetimi” olarak kullanıldığını ve bu kavramın daha yaygın olarak kullanıldığını görmekteyiz.

Afetlerle mücadele yaklaşımlarının evrimi doğal olarak afet deneyimleri ve geçmiş afetlerden edinilen bilgi ve alınan dersler ile gelişmektedir. Deprem, sel, toprak kayması, çığ, kaya düşmesi vb. doğal afetlerin nerelerde daha az nerelerde daha çok olacağı hala kesin olarak hesaplanamamaktadır. Bilimsel gelişmeler sonucunda afetler hakkında bildiklerimiz aslında sadece tahminlerden ibarettir. Bu gibi felaketlerin insan eliyle engellenmesi mümkün olmadığından, bu süreçte doğa veya insan kaynaklı afetler sonucunda oluşabilecek zararların önceden alınacak tedbirler neticesinde en aza indirilmesi amaçlanmalıdır. Her afet etkilediği toplum üzerinde bir takım izlerle birlikte ders alınması gereken sonuçlar da bırakmaktadır. Ancak özellikle geniş bir alanı etkileyen ve ağır hasar veren kimi afetler diğerlerine göre etkiledikleri toplumlar üzerinde kapanması daha güç yaralar açmaktadır ${ }^{2}$.

Afet yönetimi; yalnızca bir disiplinin değil birden fazla bilim dalının ortak çalışması ile ele alınması ve incelenmesi gereken bir konudur. Ayrıca, afetlerin olası etki ve sonuçları toplumun her kesimini ilgilendirir; belirli bir kesim ya da kurumun çabalarının ötesinde birliktelik ve ortak mücadele gerektirir. Dolayısıyla, afet yönetiminde, kamu kurum ve kuruluşları, özel sektör, akademik kuruluşlar, sivil toplum kuruluşları, medya ve bireyler olmak üzere toplumun her kesimi ve uluslararası kuruluşlar da yer alır. Etkili bir afet yönetimi için ortak bir duyarlılıkla her bir kurumun sorumluluk üstlenerek koordinasyon ve işbirliği içinde olması gerekir ${ }^{3}$.

1982 Anayasası'nın 5. Maddesi, devletin temel amaç ve görevlerini, " Türk milletinin bağımsızlığını ve bütünlüğünü, ülkenin bölünmezliğini, Cumhuriyeti ve demokrasiyi korumak, kişilerin ve toplumun refah, huzur ve mutluluğunu sağlamak; kişinin temel hak ve hürriyetlerini, sosyal hukuk devleti ve adalet ilkeleriyle bağdaşmayacak surette sınırlayan

\footnotetext{
${ }^{2}$ Press F., Hamilton R. M., "Mitigating Natural Disasters", Science, Vol.284, Issue:5422, 1999

http://science.sciencemag.org/content/284/5422/1927.

${ }^{3}$ Türkiye Afet Yönetimi Strateji Belgesi, 10.06.2015, s.11-12.
} 
siyasal, ekonomik ve sosyal engelleri kaldırmaya, insanın maddi ve manevi varlığının gelişmesi için gerekli şartları hazırlamaya çalışmaktır" şeklinde ifade etmektedir.

Afet yönetimi ve buna ilişkin faaliyetler, bir ülkede idare tarafından ya da idarenin gözetim ve denetimi altında yerine getirilmesi gereken nitelikte faaliyetlerdir. Gerçekten de Anayasa' nın 5'inci maddesindeki, " kişilerin ve toplumun refah, huzur ve mutluluğunu sağlamak" ifadesine dayanarak, idarenin afetlere ilişkin yürüteceği faaliyetlerin de devletin temel amaç ve görevleri arasında olduğu şeklinde bir yorum yapılabilir ${ }^{4}$. İşte idare, afet yönetimi ile ilgili mevzuat kapsamında, afet yönetimine ilişkin faaliyetleri ulusal ölçekte planlamak, koordine etmek ve uygulamakla bu yöndeki amaç ve görevlerini yerine getirmiş olmaktadır.

Afetlerin önlenmesi ve afet zararlarının azaltılabilmesi için, öncelikle afete yol açabilecek tehlike ve risklerin iyi bilinmesi gerekmektedir. Özellikle afete yol açan olaylar gerçekleşmeden önce önleyici tedbirlerin alınması, gerçekleştikten sonra ise en akılcı yol ve yöntemlerle bunların ortadan kaldırıması veya afetlerin yol açabilecekleri olumsuz etkilerin azaltılmasını gerektiren topyekûn bir mücadele süreci olarak kabul edilen afet yönetim sürecinde; en sade bireyden en yetkili makamlara kadar, herkese görev ve sorumluluk düşmektedir ${ }^{5}$. Iş̧te bu sebeplerle, afetlerin meydana getirdiği olumsuzlukları tüm yönleriyle ortadan kaldırmak için, afet yönetim sisteminin işbirliği içerisinde ve başarılı bir şekilde yürütülmesi büyük bir öneme sahiptir.

\section{2- $\quad$ Afet Yönetimine İlişkin Yasal Düzenlemeler}

1959 yılı ve sonrası dönem, ülkemizde afet zararlarının azaltılması için uluslararası alandaki gelişme ve değişmelere paralel olarak, önemli kurumsal yapılanma ve siyasi değişikliklerin meydana geldiği yıllar olmuştur. Bunlardan en önemlisi 1959 yılında çeşitli değişikliklerle halen yürürlükte olan 7269 Sayılı "Umumi Hayata Müessir Afetler Dolayısıyla Alınacak Tedbirlerle Yapılacak Yardımlara Dair Kanun "' un çıkarılmasıdır. Bu kanun ile afet zararlarının azaltııması için afet öncesi, sırası ve sonrasında yapııması gereken çalışmalar düzenlenmiştir. Kanun'a göre; afet olayı meydana geldikten sonra ilk olarak afetin genel hayata etkili olup olmadığına dair karar verilmekte ve bu karar uyarınca afetin meydana geldiği yerde çalışmalar planlanmaktadır. Ardından arama, kurtarma, ilkyardım, acil yardım, hasar tespiti, geçici barınma, hak sahiplerinin belirlenmesi, yeni yerleşim yerlerinin belirlenmesi ve kalıcı konutların yapımı, devir ve temliki gibi aşamalardan oluşan bir süreç başlamaktadır. Ayrıca söz konusu kanunun en önemli özelliği afet zararlarını azaltmayı amaçlayan daha önceki tüm yasaları tek bir yasa haline getirmesi ve afet öncesi, sırası ve sonrasında yapılan çalışmaların bir bütçeye dayandırılmasıdır.

Konuya ilişkin Anayasal hükümleri ele alacak olursak, 21.01.2017 tarih ve 6771 sayılı "Türkiye Cumhuriyeti Anayasasında Değişiklik Yapılmasına Dair Kanun" un 12. maddesi ile 2709 Sayılı 1982 Anayasası'nın 119 uncu maddesi başlığıyla birlikte değiştirilmiştir. 6771 Sayılı Kanunla değişik 1982 Anayasası'nın "Olağanüstü Hal Yönetimi” başlıklı 119 uncu maddesi; "Cumhurbaşkanı; savaş, savaşı gerektirecek bir durumun baş göstermesi, seferberlik, ayaklanma, vatan veya Cumhuriyete karşı kuvvetli ve eylemli bir kalkışma, ülkenin ve milletin bölünmezliğini içten veya dıştan tehlikeye düşüren şiddet hareketlerinin yaygınlaşması, anayasal düzeni veya temel hak ve hürriyetleri ortadan kaldırmaya yönelik yaygın şiddet hareketlerinin ortaya çıkması, şiddet olayları nedeniyle kamu düzeninin ciddî şekilde bozulması, tabiî afet veya tehlikeli salgın hastalık ya da ağır ekonomik bunalımın

\footnotetext{
${ }^{4}$ Şahin, A. U.(2014), " Afet Yönetimi Faaliyetlerinin Kamu Hizmeti Kavramı Çerçevesinde Değerlendirilmesi”, Tesam Akademi Dergisi, Temmuz, 1(2), s. 12.

${ }^{5}$ Ergünay, O., "Afet Yönetimi: Genel İlkeler, Tanımlar, Kavramlar”, Acil ve Afet Dergisi, Cilt.2, Sayı.4, Acil ve Afet Derneği, Ankara, 2014, s.70.

${ }^{6}$ R.G. 25.05.1959 tarih ve 10213 sayı.

${ }^{7}$ R.G. 11.02.2017 tarih ve 29976 sayı.
} 
ortaya çıkması hallerinde yurdun tamamında veya bir bölgesinde, süresi altı ayı geçmemek üzere olağanüstü hal ilan edebilir" şeklini almıştır. 1982 Anayasası'nın olağanüstü hal durumunu düzenleyen 120. maddesi ile sıkıyönetim durumunu düzenleyen 122. maddesi ise; 6771 Sayılı Kanun'un 16/E maddesiyle yürürlükten kaldırılmıştır.

Yasal düzenlemeler açısından, Türkiye'de afet yönetimi ve koordinasyonu alanında dönüm noktası 17 Ağustos 1999 Marmara Depremi'dir. Büyük can kaybına ve geniş çaplı hasara neden olan bu deprem, ülkemizde afet yönetimi konusunun tekrar gözden geçirilme zorunluluğunu acı bir şekilde ortaya koymuştur. Marmara depreminin hemen ardından, bölgede normal yaşama dönülebilmesi, bölgenin ekonomisinin düzeltilmesi ve gereken yasal önlemlerin ivedilikle alınabilmesi amacıyla, 27.08.1999 tarih ve 4452 Sayılı " Doğal Afetlere Karşı Alınacak Önlemler ve Doğal Afetler Nedeniyle Doğan Zararların Giderilmesi İçin Yapılacak Düzenlemeler Hakkında Yetki Kanunu çıkarılmış ve bu Yetki Kanunu'na dayanılarak; 17 Ağustos 1999'dan 2000 yılı Temmuz ayının başına kadar geçen dönemde birçok kanun, KHK, tüzük ve yönetmelik çıkarılmıştır ${ }^{8}$. Bu düzenlemelerle, hem depremin neden olduğu sorunların çözülmesi hem de ülkenin afet yönetimi konusunda kurumsal yapılanma ve mevzuat ile ilgili sıkıntılarının ve eksikliklerinin giderilmesi amaçlanmıştır ${ }^{9}$.

Marmara depreminin ardından kurumsal anlamda yapılan en önemli değişiklik, 22 Kasım 1999 tarih ve 23884 sayılı mükerrer Resmi Gazete' de yayımlanan, 583 Sayılı "Başbakanlık Teşkilatı Hakkında Kanun Hükmünde Kararnamenin Değiştirilerek Kabulü Hakkında Kanunda Değişiklik Yapılmasına Dair Kanun Hükmünde Kararname" dir. Aynı kararnamenin 3. Maddesi ile; acil durum yönetiminin etkin bir şekilde gerçekleştirilmesi amacıyla kamu kurum ve kuruluşlarında acil durum yönetimi merkezlerinin kurulmasını sağlamak, çalışma esaslarını belirlemek ve bu merkezler arasında koordinasyonu sağlamak, acil durum yönetimi gerektirecek olayların önlenmesi ve zararlarının azaltılması için kurum ve kuruluşlarca gerekli önlemlerin alınmasını, kısa ve uzun vadeli planların hazırlanmasını ve bilgi bankalarının kurulmasını izlemek ve değerlendirmek, acil durum yönetimine geçilen hallerde, kamu ve özel sektöre ait her türlü kara, deniz ve hava taşıtları ile kurtarma ve yardım araç ve gereçlerinden yararlanılmasında koordinasyon hizmetlerini yürütmek, acil durumlarda yardım sağlayan gönüllü kuruluş ve kişiler için teşvik edici düzenlemeler yapmak, yardım malzemelerinin teslim alınmasını, korunmasını ve ihtiyaç noktalarına sevk edilmesinde koordinasyonu sağlamak görevlerini üstlenmiş olan "Türkiye Acil Durum Yönetimi Başkanlığı" kurulmuştur ${ }^{10}$.

Türkiye Acil Durum Yönetimi Başkanlığı 14 Haziran 2000 tarih ve 24079 sayılı Resmi Gazete' de yayımlanan 600 Sayılı "Başbakanlık Teşkilatı Hakkında Kanun Hükmünde Kararnamenin Değiştirilerek Kabulü Hakkında Kanunda Değişiklik Yapılmasına Dair Kanun Hükmünde Kararname" ile görevleri aynı kalarak, "Türkiye Acil Durum Yönetimi Genel Müdürlüğü" ne dönüştürülmüştür ${ }^{11}$.

4452 sayılı Yetki Kanununa dayanılarak çıkarılan ve 27.12.1999 tarih ve 23919 (mükerrer) sayılı Resmi Gazete'de yayımlanarak yürürlüğe giren 586 Sayılı "Sivil Müdafaa Kanunu ile Belediye Kanununda Değişiklik Yapılmasına Dair Kanun Hükmünde Kararname" ile 11 ilde merkeze bağlı sivil savunma birlikleri, illerde sivil savunma arama kurtarma birlikleri ve ilçelerde de sivil savunma müdürlükleri kurulmuştur. Ayrıca ilgili kararname ile, meydana

\footnotetext{
${ }^{8}$ Fani R., “Erciş Depremi Özelinde Türkiye'de Afet Yönetimi”, YYÜ SBE Kamu Yönetimi Ana Bilim Dalı, Yayımlanmamış Yüksek Lisans Tezi, Van, 2014, s.29.

${ }^{9}$ Ergünay, (Afet Mevzuatı), s.5.

${ }^{10}$ http://www.resmigazete.gov.tr/main.aspx?home=http://www.resmigazete.gov.tr/arsiv/23884 1.pdf\&main=http://www.resmigaz ete.gov.tr/arsiv/23884 1.pdf, Erişim Tarihi: 29.09.2017.

${ }^{11}$ http://www.resmigazete.gov.tr/main.aspx?home=http://www.resmigazete.gov.tr/arsiv/24079.pdf\&main=http://www.resmigazete gov.tr/arsiv/24079.pdf, Erişim tarihi: 27.07.2017.
} 
gelen afetlerde belediyelerin sorumluluk alanları dışında görev alabilmesi ve gönüllü kuruluşların arama kurtarma hizmetlerine katılması esasları da düzenlenmiştir ${ }^{12}$.

586 Sayılı KHK'yı takiben, yaşanan Marmara depreminin ardından konutları yıkılan veya ağır hasar gören kişilerin barınma intiyacı nedeniyle yapılan kalıcı konutların maliyetinin kamu finansmanına ciddi yükler getirmesi nedeniyle, kamunun yüklerini hafifletmek amacıyla, 4452 sayılı Yetki Kanununa dayanılarak hazırlanan 587 sayılı "Zorunlu Deprem Sigortası'na Dair Kanun Hükmünde Kararname" 27.12.1999 tarihinde yayımlanmış ve 27.09.2000 tarihinde yürürlüğe girmiştir ${ }^{13}$. Bu KHK ile zorunlu deprem sigortası işlerini yürütmek üzere kamu tüzel kişiliğini haiz olan Doğal Afet Sigortaları Kurumu (DASK) kurulmuştur. 18.05.2012 tarihinde yayımlanan 6305 sayılı "Afet Sigortaları Kanunu" ile de kurum daha sağlam bir yasal çerçeveye kavuşturulmuştur. Yeni Kanunla birlikte; tapu ve konut kredisi işlemlerine ek olarak elektrik ve su abonelik işlemlerinde de ZDS kontrolüne başlanmış ve diğer doğal afetler için de DASK tarafından teminat sunulması mümkün kılınmıştır ${ }^{14}$.

\section{3- Zorunlu Deprem Sigortası (ZDS) ve Doğal Afet Sigortaları Kurumu (DASK)}

\subsection{Amaç ve Kapsam}

6305 Sayılı Afet Sigortaları Kanunu'nun amacı, binalarda deprem sonucu meydana gelebilecek maddi zararların karşılanmasını teminen yaptıılacak zorunlu deprem sigortası ile sigorta şirketlerince teminat verilemeyen veya teminat verilmesinde güçlükler bulunan çeşitli afetler ve riskler sonucu meydana gelebilecek maddi ve bedeni zararların karşılanabilmesini teminen sunulacak sigorta ve reasürans teminatlarına ilişkin usul ve esasları belirlemektir ${ }^{15}$.

Deprem sırasında ortaya çıkan hasarlar ve yaşanan kayıplar nedeniyle, deprem sonrası toplumda yaşanan manevi çöküntünün yanı sıra depremde maddi zarara uğrayanlar için teselli niteliğinde olacak maddi desteğin kısa sürede ve tam olarak sağlanamaması, kaynak intiyacının boyutu ve bu durumun devletin imkanlarını da zorlayarak dış yardımı zorunlu kılması DASK'ın ortaya çıkışını etkileyen en önemli faktörler olarak görülmektedir ${ }^{16}$.

DASK' ın temel amaçları ise; ZDS kapsamındaki bütün konutları ödenebilir bir prim karşılığında sigorta kapsamına almak, devletin depremlerden kaynaklanan malî yükünü azaltmak, sigorta yoluyla risk paylaşımını sağlamak, sigorta sistemini sağlıklı yapı üretiminde bir araç olarak kullanmak, deprem hasarlarının karşılanması için uzun vadeli kaynak birikimini temin etmek olarak sıralanabilir ${ }^{17}$.

Zorunlu Deprem Sigortası genel anlamıyla, belediye sınırları içinde kalan meskenlere yönelik olarak geliştirilmiş bir sigorta sistemidir. 6305 sayılı Afet Sigortaları Kanunu gereğince, aşağıda tanımlanmış binalar güvence altına alınır:

- Tapuya kayıtlı ve özel mülkiyete tabi taşınmazlar üzerinde mesken olarak inşa edilmiş binalar,

- 634 sayılı Kat Mülkiyeti Kanunu kapsamındaki bağımsız bölümler,

\footnotetext{
${ }^{12}$ Ergünay (Afet Mevzuatı), s.5.

${ }^{13}$ Fani, a.g.e., s.29.

${ }^{14}$ Taylan, A., "Zorunlu Deprem Sigortası ve Kentsel Risk Yönetimi", Planlama Dergisi, TMMOB Şehir Plancıları Yayını, Sayl:2007/2, Yıl: 2007, s.23.

${ }^{15} 6305$ Sayılı Kanun m.1

${ }_{16}$ Gürlek, Y., "Türkiye'de ve Dünya'da Deprem Sigortacılığı", İstanbul Teknik Üniversitesi Fen Bilimleri Enstitüsü, Yayınlanmamış Yüksek Lisans Tezi, Haziran 2006, s.38.

${ }^{17}$ Doğan B., "Türkiye'de Afet Yönetim Politikalarının Analizi: Paydaşlar, Etkinlik ve Sorunlar", Sakarya Üniversitesi 6. Kamu Politikaları Çalıştayı Bildiriler Kitabı, 16-18 Eylül 2015, s.7; Gürlek, a.g.e.,s.39.
} 
- Bu binaların içinde yer alan ve ticarethane, büro ve benzeri amaçlarla kullanılan bağımsız bölümler,

- Doğal afetler nedeniyle devlet tarafından yaptırılan veya verilen kredi ile yapılan meskenler ${ }^{18}$.

Zorunlu Deprem Sigortası ayrıca yukarıdaki koşullara uyan;

- Kat irtifakı tesis edilmiş binalar,

- Tapuda henüz cins tashihi yapılmamış ve tapu kütüğünde vasfı "arsa vs." olarak görünen binalar,

- Tapu tahsisi henüz yapılmamış kooperatif evleri, için de geçerlidir.

Buna karşılık,

- 09/11/1983 tarihli ve 2946 sayılı Kamu Konutları Kanunu'na tâbi olan veya kamu hizmet binası olarak kullanılan binalar ve bağımsız bölümler,

- Köy nüfusuna kayıtlı ve köyde sürekli oturanlarca köy yerleşik alanları ve civarında ve mezralarda yapılan binalar ile,

- 634 sayılı Kanun kapsamında olsalar dahi tamamı ikamet dışı amaçlarla kullanılan binalar ${ }^{19}$, zorunlu deprem sigortasına tâbi değildir.

\subsection{Sigortalanma Oranı}

DASK, Zorunlu Deprem Sigortası ile olası bir deprem felaketinden sonra, sigorta sahiplerinin hayatlarına kaldığı yerden yeniden güvenle devam edebilmelerini amaçlar. "Deprem geçecek, hayat devam edecek..." diyen DASK, her yıl inşaat maliyetlerindeki artışa göre belirlediği azami bir tutarda teminat sağlamaktadır. DASK tarafından verilen azami teminat tutarı, 17 Ocak 2018 tarihinden itibaren bütün yapı tiplerinde 190 Bin TL'dir. Azami teminat tutarı tespit edilirken, yıkılan meskenin yeniden inşa edilmesinin maliyeti (arsa değeri hariç) dikkate alınır. Sigortalının teminat tutarı (sigorta bedeli) -azami teminat tutarını geçmemesi koşuluyla- meskenlerinin büyüklüğüne ve yapı tarzına göre belirlenir ${ }^{20}$.

Uygulanan politikalar sonucu, afetleri kader olarak görme eğilimi yerine afetlerin hem insan kaynaklı hem de doğa kaynaklı olduğu anlayışı yerleşmeye başlamıştır. Buna rağmen riskler konusunda yeterli farkındalık sağlanamamıştır. Örneğin zorunlu deprem sigortası uygulamasına katıım oranı, ilgili yasalara rağmen 47.3 te kalmıştır.

Tablo 1: Bölgelere göre zorunlu deprem sigortasına katılım oranı.

\begin{tabular}{|c|c|c|c|c|c|c|}
\hline BÖLGE & $\begin{array}{l}\text { KONUT } \\
\text { SAYISI }\end{array}$ & $\begin{array}{l}\text { SIGORTALI } \\
\text { KONUT } \\
\text { SAYISI }\end{array}$ & $\begin{array}{l}\text { POLIÇE } \\
\text { AĞILIMI }\end{array}$ & $\begin{array}{l}\text { SIGORTALILIK } \\
\text { ORANI }\end{array}$ & PRIM & $\begin{array}{l}\text { PRIM } \\
\text { ORANI }\end{array}$ \\
\hline MARMARA & 6.014 .550 & 3.455 .249 & $\% 41,30$ & $\% 57,40$ & 487.870 .576 & $\% 47,20$ \\
\hline IÇ ANADOLU & 3.332 .500 & 1.522.077 & $\% 18,20$ & $\% 45,70$ & 103.747 .870 & $\% 10,00$ \\
\hline EGE & 2.616 .350 & 1.194 .879 & $\% 14,30$ & $\% 45,70$ & 188.872 .899 & $\% 18,30$ \\
\hline AKDENIZ & 2.236 .030 & 896.031 & $\% 10,70$ & $\% 40,10$ & 103.938 .556 & $\% 10,10$ \\
\hline KARADENIZ & 1.693 .780 & 665.144 & $\% 8,00$ & $\% 39,30$ & 74.291.191 & $\% 7,20$ \\
\hline $\begin{array}{l}\text { GÜNEY DOĞU } \\
\text { ANADOLU }\end{array}$ & 991.460 & 331.742 & $\% 4,00$ & $\% 33,50$ & 32.658 .959 & $\% 3,20$ \\
\hline DOĞU ANADOLU & 777.020 & 295.662 & $\% 3,50$ & $\% 38,10$ & 42.832.348 & $\% 4,10$ \\
\hline TOPLAM & 17.661 .690 & 8.360 .784 & $\% 100$ & $\% 47,30$ & 1.034.212.399 & $\% 100$ \\
\hline
\end{tabular}

\footnotetext{
${ }^{18}$ Madde 10/f1

${ }^{19}$ Madde 10/f2

20 Dask (2018), Doğal Afet Sigortaları Kurumu, https://www.dask.gov.tr/zorunlu-deprem-sigortasi-istatistikler-2.html, Erişim Tarihi: 08.02.2018.
} 


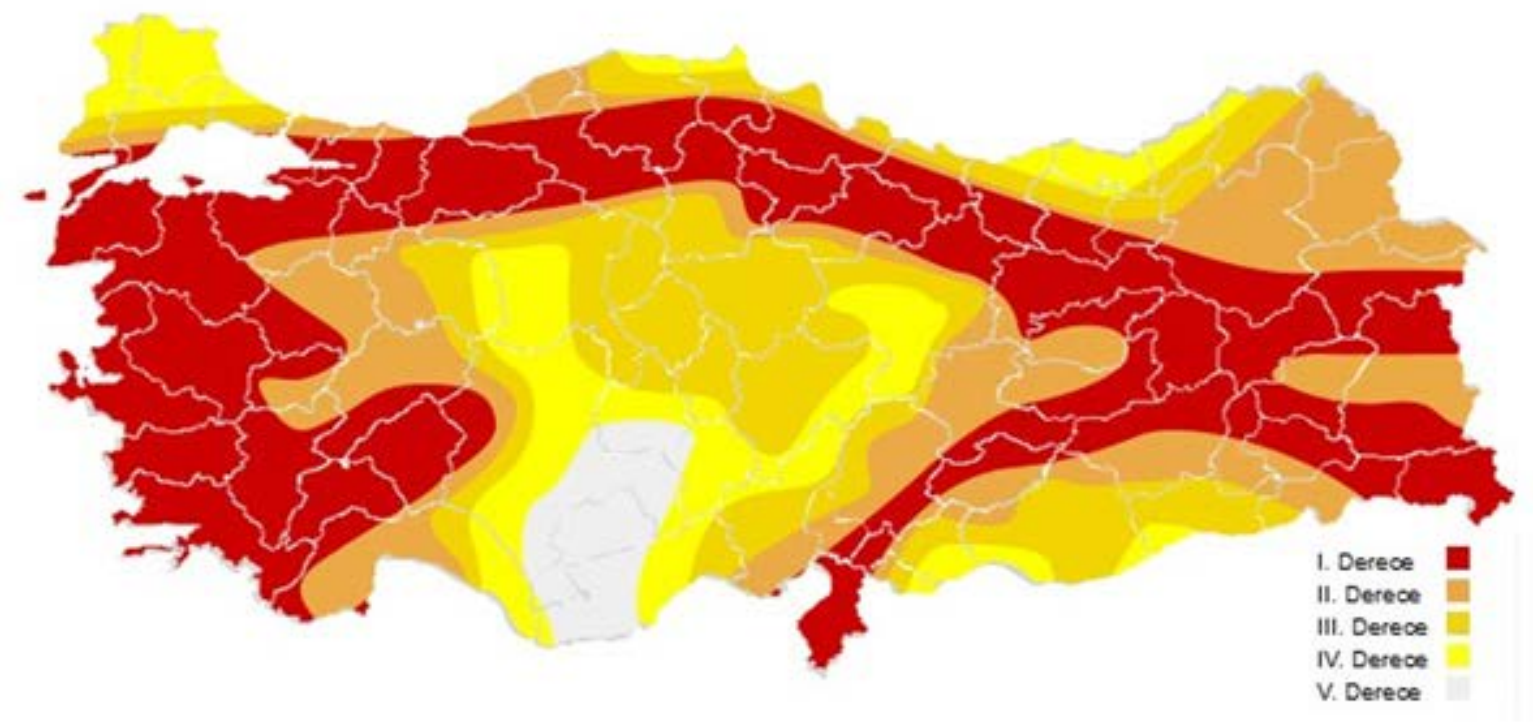

Şekil 1. Türkiye Geneli Deprem Tehlike Haritası (URL-1).

Bölgelere göre zorunlu deprem sigortası katılım oranı ile Türkiye geneli deprem tehlike haritasını beraber okuduğumuzda, Türkiye gibi hem doğa kaynaklı hem de insan kaynaklı afetlerin oldukça fazla yaşandığı bir ülke için, zorunlu deprem sigortası uygulamasına katıım oranının -ki bu oranın, elektrik ve su abonelik işlemlerinde de ZDS kontrolüne başlanmasıyla birlikte arttığı düşünüldüğünde- \% 47.3 gibi bir oranda kalması, hem riskler konusunda yeterli farkındalığın sağlanamamış olduğunu hem de insanların deprem gerçeği ve tehlikesini hafife aldıklarını söyleyebiliriz. İşte, öncelikle AFAD ve ilgili kamu kurumları tarafından halk arasında yeterli farkındalığın sağlanması, sigortalılık oranının artırılması yönünde yeni yasal düzenlemelerin yapılması, ZDS' nin kapsamının genişletilmesi ve deprem gerçeğine uygun bir afet yönetimi politikasının izlenmesi yararlı adımlar olarak sıralanabilir.

4452 sayılı Yetki Kanunu'na dayanılarak hazırlanan, 10 Nisan 2000 tarih ve 24016 sayılı Resmi Gazete' de yayımlanarak yürürlüğe giren diğer düzenleme, 595 Sayılı "Yapı Denetimi Hakkında Kanun Hükmünde Kararname" dir. 595 Sayılı KHK ile; yapılarda can ve mal güvenliğini sağlamak, plansız, kontrolsüz ve kalitesiz yapılaşmayı önleyerek kaynak israfını ortadan kaldırmak, çağdaş norm ve standartlarda yapı üretmek ve bunun için yapı denetimini sağlamak, yapıda meydana gelen hasarlar nedeniyle zarara uğrayan kişilerin haklarını korumak ve doğması muhtemel zararların tazmin edilmesini sağlamak amaçlanmıştı ${ }^{21}$.

Marmara depreminin ardından başlayan kurumsal değişim ve dönüşüm sonrasında, eşgüdüm sağlanması gereken kurumların afetlerle ilgili yetki ve sorumluluklarının yeniden tanımlanması intiyacı afet ve acil durumlarda yetki ve koordinasyonun tek bir elde toplanmasını gerekli kılmıştır. Bu doğrultuda afetlerle ilgili olarak görev yapan Sivil Savunma Genel Müdürlüğü, Afet İşleri Genel Müdürlüğü ve Türkiye Acil Durum Yönetimi Genel Müdürlüğü kapatılmış, 2009 yılında çıkarılan 5902 sayılı "Afet ve Acil Durum Yönetimi Başkanlığının Teşkilat ve Görevleri Hakkında Kanun" ile Başbakanlık'a bağlı Afet ve Acil Durum Yönetimi Başkanlığı kurularak yetki ve sorumluluklar tek bir çatı altında toplanmıştır ${ }^{22}$.

23 Ekim 2011 ve 9 Kasım 2011 Van ve Erciş depremleri sonrasında çok fazla yapının yıkılması ve zarar görmesi afet riski altında bulunan bölgelerdeki yapıların dönüştürülmesi, afet riski altındaki alanlar ile bu alanlar dışındaki riskli yapıların bulunduğu arsa ve arazilerde,

\footnotetext{
${ }^{21}$ Fani, a.g.e., s.29.

${ }^{22}$ https://www.afad.gov.tr/tr/2211/AFAD-Hakkinda, Erişim Tarihi: 27.07.2017.
} 
fen ve sanat norm ve standartlarına uygun, sağlıklı ve güvenli yaşama çevrelerini teşkil etmek üzere iyileştirme, tasfiye ve yenileme çalışmaları amacıyla; 6306 Sayılı " Afet Riski Altındaki Alanların Dönüştürülmesi Hakkında Kanun”, 31 Mayıs 2012 tarih ve 28309 sayılı Resmi Gazete' de yayımlanarak yürürlüğe girmiştir ${ }^{23}$.

$\mathrm{Bu}$ Kanunun amacı ise; afet riski altındaki alanlar ile bu alanlar dışındaki riskli yapıların bulunduğu arsa ve arazilerde, fen ve sanat norm ve standartlarına uygun, sağlıklı ve güvenli yaşama çevrelerini teşkil etmek üzere iyileştirme, tasfiye ve yenileme çalışmaları yapmaktır.

\section{Sonuç}

1999 sonrası dönemde afet sonrası politikalarda daha etkin ve sürdürülebilir müdahale, iyileştirme ve yeniden inşa yaklaşımlarının benimsenmesinin yanı sıra afet öncesi politikalarda risk azaltma ve hazırlık çalışmaları önem kazanmaya başlamıştır. 2009 sonrasında AFAD 'ın kurulması ile Dünya'da değişen ve dönüşen afet politikalarına uygun bir politika belirleme süreci yaşanmıştır. Bu süreçte politikaların etkin uygulanabilmesi için, yasal altyapı, teknik gelişmelere uyumluluk, personel ihtiyacının karşılanması, sivil toplumun ve vatandaşların desteği gibi bileşenlerin de sürece etkin bir şekilde dahil edilmesi, koordinasyonun sağlanması gibi önlemlerin alınması gereği ortaya çıkmıştır.

Yine, 18.05.2012 tarihinde yayımlanan 6305 sayılı "Afet Sigortaları Kanunu" ile de daha sağlam bir yasal çerçeveye kavuşturulan DASK hem deprem hem de diğer doğal afetler sırasında ortaya çıkan hasarlar ve yaşanan kayıplar nedeniyle, toplumda yaşanan manevi çöküntünün yanı sıra maddi zarara uğrayanlar için de teselli niteliğinde olacak maddi desteğin kısa sürede ve tam olarak sağlanmasına vesile olarak, büyük bir boşluğu doldurmuştur.

Çalışmanın ilgili kısmında dile getirdiğim üzere; bölgelere göre zorunlu deprem sigortası katıım oranı ile Türkiye geneli deprem tehlike haritasını beraber okuduğumuzda, Türkiye gibi hem doğa kaynaklı hem de insan kaynaklı afetlerin oldukça fazla yaşandığı bir ülke için, zorunlu deprem sigortası uygulamasına katılım oranının \% 47.3 gibi bir oranda kalması, hem riskler konusunda yeterli farkındalığın sağlanamamış olduğu hem de insanların deprem gerçeği ve tehlikesini hafife aldıklarını söyleyebiliriz. İşte, öncelikle AFAD ve ilgili kamu kurumları tarafından halk arasında yeterli farkındalığın sağlanması, sigortalılık oranının artırılması yönünde yeni yasal düzenlemelerin yapılması, ZDS' nin kapsamının genişletilmesi ve deprem gerçeğine uygun bir afet yönetimi politikasının izlenmesi yararlı adımlar olarak sıralanabilir. Ayrıca, ZDS sisteminin sorunlarının çözülmesi için, gelişmiş ve afet riski altındaki ülkelerin afet sigortası deneyimleri ve bu alandaki önerileri dikkate alınmalıdır. Ancak gelişen bir ülke olarak da kendi sorunlarımızı da göz önünde bulundurmalıyız.

Bu bağlamda Türk kamu yönetiminde karmaşık ve bir o kadar hassas bir kamu politikası alanı olan afet yönetimi alanında çalışmaların derinleştirilmesi gerekmektedir. Böylece ülkemizde yaşanan afetlerde meydana gelen maddi ve manevi kayıpların önüne geçilebilecektir.

\footnotetext{
${ }^{23}$ http://www.resmigazete.gov.tr/main.aspx?home=http://www.resmigazete.gov.tr/eskiler/2012/05/20120531.htm\&main=http://ww w.resmigazete.gov.tr/eskiler/2012/05/20120531.htm, Erişim Tarihi: 02.10.2017.
} 


\section{KAYNAKÇA}

DASK (2018), Doğal Afet Sigortaları Kurumu, https://www.dask.gov.tr/zorunlu-depremsigortasi-istatistikler-2.html.

Doğan B., "Türkiye'de Afet Yönetim Politikalarının Analizi: Paydaşlar, Etkinlik ve Sorunlar", Sakarya Üniversitesi 6. Kamu Politikaları Çalıştayı Bildiriler Kitabı, 16-18 Eylül 2015.

Ergünay, O., "Afet Yönetimi: Genel İlkeler, Tanımlar, Kavramlar", Acil ve Afet Dergisi, Cilt.2, Sayı.4, Acil ve Afet Derneği, Ankara, 2014.

Fani R., " Erciş Depremi Özelinde Türkiye'de Afet Yönetimi”, YYÜ SBE Kamu Yönetimi Ana Bilim Dalı, Yayımlanmamış Yüksek Lisans Tezi, Van, 2014.

Gürlek, Y., “ Türkiye'de ve Dünya'da Deprem Sigortacılığı”, İstanbul Teknik Üniversitesi Fen Bilimleri Enstitüsü, Yayınlanmamış Yüksek Lisans Tezi, Haziran 2006.

Press F., Hamilton R. M., "Mitigating Natural Disasters", Science, Vol.284, Issue:5422, 1999, http://science.sciencemag.org/content/284/5422/1927.

Şahin, A. U.(2014), " Afet Yönetimi Faaliyetlerinin Kamu Hizmeti Kavramı Çerçevesinde Değerlendirilmesi”, Tesam Akademi Dergisi, Temmuz, 1(2).

Taylan, A., "Zorunlu Deprem Sigortası ve Kentsel Risk Yönetimi”, Planlama Dergisi, TMMOB Şehir Plancıları Yayını, Sayı:2007/2, Yıl: 2007,

Türkiye Afet Yönetimi Strateji Belgesi, 10.06.2015.

\section{İnternet Kaynakları:}

URL-1: https://www.afad.gov.tr.

URL-2: http://www.resmigazete.gov.tr.

URL-3: https://www.dask.gov.tr/zorunlu-deprem-sigortasi-istatistikler-2.html. 